\title{
BUSSINESS ENTERPRISES AND HUMAN RIGHTS STANDARDS
}

\author{
M.K.Geethani Jeewanthi, \\ University of Jaffna, Sri Lanka. \\ Mkgj26@Yahoo.Com
}

\begin{abstract}
:
Globalization and other developments of the world have directed business corporations to play an increasingly vital role at both international and national levels. The number of businesses increase day by day and, consequently this has led policy makers to consider whether these business corporations have any kind of adverse effects on stake holders. Neglecting other human rights is one such unfavorable concern which would be caused by a business and this research paper intends to discuss about this issue. The main objective of this research paper is to identify the recognized human rights principles that have to be followed by business cooperations in their daily activities. This research would look for available international conventions, guidelines, principles, policies and available domestic materials which govern this research area. From the theoretical aspect the author has used the human rights based approach for this study and the doctrinal qualitative research method as its main methodology. In conclusion, notes that there is a challenge of balancing economic growth and human rights protection at all levels. While appreciating the efforts taken at global level for providing responsibility for business enterprises to protect human rights, it is also noted that there are lacunas to be addressed further.
\end{abstract}

Key Words: business enterprises, human rights, guiding principles 


\subsection{Introduction.}

Human rights are widely acknowledged to be moral claims that human beings can make in virtue of their humanity (Hazenberg, 2015). In the very early stages, the main purpose of human rights was to regulate the relationship between individuals and state and state parties were responsible for providing the protection of human rights of the individuals concerned in their respective countries. However, with the passage of time globalization emerged and it increased the role and functions of cooperate actors at all levels. The issue of human rights is central to good corporate citizenship and to a healthy bottom line (Robinson, 2000). Taking that into account, human rights issues have become extremely important because State power seems to be weakening and influential business corporations that threaten and abuse human rights are emerging (Hazenberg, 2015). Thus, it creates a space between the scope and impact of economic forces and actors, and the capacity of societies to manage their adverse effects (Whelan et al, 2009). This means that even though a free market economy is needed for State development, human rights included, effective sanctioning or reparation mechanism is a necessity as well, since these governance gaps create a permissive environment for unlawful acts by Business Corporations (Ruggie, 2008).Consequently this situation has been a main discussion of human rights organization including the United Nations (UN). The UN is the main body responsible for upholding human rights. The UN was established in 1947 after the 2nd world war under the Charter of the United Nations and according to the preamble of the Charter, it is very clear that one of the core objectives of establishing the $\mathrm{UN}$ is to protect human rights globally. The UN is working in many aspects relates to human right and business and human rights is one such major concern.

In the introduction the author describes the main functions of conducting this research including objectives, methodology, limitations and theoretical background. In the first part of the discussion section, the author describes the general picture of human rights at global level which encompasses many writings on UN and its human rights standards. Furthermore paper inquires about the example of realistic situations occurring globally on human rights issues caused by business corporations. In the second part of the discussion the author specifically lists out and describes each attempt taken by global actors regarding the issue of human rights and business. Following that this paper will discuss in detail about the principles that have to be 
followed by business cooperation in their day to day activities. Finally the critical assessment of the above materials and implementation will be discussed in the analysis and conclusion section.

\subsection{Objective of the study}

The main objective of this research paper is to identify the recognized human rights principles that have to be followed by business corporations in their day to day activities. This paper also would serve as a guiding document which consists of materials governing the area of business and human rights. One sub objective is to critically analyse the practical applicability of the said principles and to provide possible recommendations to overcome proble$\mathrm{ms}$, if any.

\subsection{Limitations}

This research is conducted as a theoretical legal study and only the legal aspects, particularly human rights law, has been selected for discuss in this paper. It is obvious there are many other factors to be discussed under the topic of business and human rights; however, this study is limited to identify and discuss the available international and other legal mechanisms/ instruments/ policies pertaining to this issue. Further although there are several laws such as criminal law and delict law, land law, environmental law etc... which are relevant to this topic, this study will discuss only about the wider area of human rights law.

\subsection{Theoretical back ground}

As a main theory of this doctrinal study the author wishes to utilize the human rights based approach. A human rightsbased approach is a conceptual framework for the process of human development that is normatively based on international human rights standards and operationally directed to promoting and protecting human rights. It seeks to analyze inequalities which lie at the heart of development problems and redress discriminatory practices and unjust distributions of power that impede the development progress (Unicef-2016). The Human right based approach also seeks redress discriminatory practices and unjust distributions of power that impede development progress (The Danish Institute for Human Rights). In particular Alberts (2013) points out the possible benefits a business operations can gain when oriented by positive human rights outcomes; beyond improved risk management, benefits could include improved stakeholder engagement and reputation advantages with revenue and cost 
benefits related to business development, client and customer satisfaction, employee engagement, talent recruitment and management, and improved relationships with suppliers and local communities (Alberts, 2013). Due to the benefits which can be acquired by every stake holder in utilizing human rights practices this research is based on the theory of the human rights based approach and to test the practicability and success ability of this method in business corporations.

\subsection{Methodology}

As mentioned in the limitation section, this research is conducted as a doctrinal study which is concerned with the formulation of legal 'doctrines' through the analysis of legal rules (Chynoweth, 2008). Chynoweth further stated that in common with other humanities' disciplines, most legal scholarship is not concerned with empirical investigation, but with the analysis and manipulation of theoretical concepts. The methodologies employed, therefore, differ from those of the sciences and are probably more accurately categorized in social science terms, as techniques of qualitative analysis. It is observed that deductive and inductive logic, the use of analogical reasoning and policy analysis feature strongly within this process. Doctrinal research Legal rules are normative in character as they dictate how individuals ought to behave (Kelsen, 1967). The doctrinal study makes no effort either to explicate, guess, or even to understand human behaviour but their one and only function is to prescribe it. In short, doctrinal research is not, therefore, research about law at all. In asking 'what is the law $\Delta$ ' it takes an internal, participant-orientated epistemological approach to its object of study (Hart, 1961) and, for this reason, is sometimes described as research in law (Arthurs, 1983).

Under this doctrinal study method, the author have utilized international conventions, guidelines, policy frameworks, declarations and many writings such as books, journal articles and web materials as sources of gathering information. The sole idea of this research is to critically synthesis the norms and rules pertaining to business and human rights. As Hart (1961) describes this study focuses on finding solutions for the question of 'what is the desired law govern business and human rights and how it balance the conflict interests $\Delta^{\prime}$ To answer this question it is not required to conduct an empirical study as pointed out by Chynoweth (2008), but it is very important to understand the theoretical concept underlining the issue. 


\subsection{Discussion}

\section{Human Rights in General}

Human rights are rights inherent to all human beings without considering nationality, place of residence, sex, national or ethnic origin, colour, religion, language, or any other status. The foundation document of human rights is the Universal Declaration of Human Rights (UDHR) which was passed in 1948. This Declaration has 30 main articles which speak about human rights and human duties. This document also complies with all types of human rights including civil, political, economic, social and cultural rights. Although the UDHR is the prime and core influential document on human rights, it was not legally binding over state parties. Due to this lacuna, later there were two major conventions which emerged in 1966; The International Conven-tion on Civil and Political Rights (ICCPR) and the International Convention on Economic, Social and Cultural Rights (ICESCR). Both these conventions cover almost all the human rights and the state parties were made responsible to ensure the protection of human rights of their respective countries. ICCPR covers the negative human rights such as freedom from torture, freedom from arbitrary arrest, freedom from being discriminated against, freedom of expression, right to privacy, right to life and etc... negative human right meaning, that a state party does not need to take active actions regarding such rights and what they expect is not to intervene in the enjoyment of the right. For example, freedom from torture is a naturally inherent right and a state is required not to disturb that natural right. On the other hand, ICESCR consists of positive rights such as right to health, right to education, right to housing, right to social protection etc... which urges Sates to take positive action to enjoy the meaningful rights. For example in order to protect the right to health, a State should construct hospitals, provide medicine and staff and train those officials. Although Human Rights were classified as negative and positive rights in Article 5 of the Vienna Declaration of Action, 1993, it was declared that human rights are universal, indivisible and interdependent and interrelated. Therefore, in the current context all the types of human rights would be considered as being equally important for human beings.

Apart from the general human rights conventions the UN also establishes some thematic UN treaties for the protection of different sets of peoples such as women, children, migrant workers, racially discriminated people, people who face torture etc... The 
conventions prepared under thematic issues for the above segments provide detailed discussions on the rights concerning those groups. For example the Convention on the Elimination of All forms of Discrimination against Women (CEDAW) has provisions to protect women from discrimination they face in their life. According to that women cannot be discriminated against due to any grounds in recruiting for any job, they should also be provided with equal pay with men of the same level in an office, their safety has to be protected by the employer and necessary leave such as maternity leave should be provided with pay. Under most of these conventions a treaty based body/ committee has been appointed and they serve in many ways for the protection of human rights. These committees would consider the State party reports submitted periodically. They also entertain the petitions sent by individuals and provide interpretations identified as general comment/ recommendations for particular articles of the conventions concerned.

\section{Particular concern on business and human rights}

This broad area of human rights can be applicable to business corporations at different levels. Some are directly applicable to business' employees such as labour law standards and some can be applicable to partners of business corporations. On the other hand, there has to be a concern on general human rights issues of community and environmental aspects. Further there can be hybrid topics which consist of both private and public issues. Having this in mind human right discourse started years back and at the closing to the 20th century the need for working with particularly business and human rights started within the United Nation. Many steps have taken at international level in relation to business and human rights.

In the year 2000 the United Nations Global Compact was launched as an initiative of the United Nation Secretary General. This is claimed as the world's largest corporate sustainability initiative. The main objective of the UN Global Impact is to mobilize a global movement of sustainable companies and stakeholders to create a world which protects human rights and for this to happen the UN Global Compact supports companies to: (1). Do business responsibly by aligning their strategies and operations with Ten principles on human rights, labour, environment and anti-corruption; and (2). Take strategic actions to advance UN Sustainable Goals, with an emphasis on collaboration and innovation. 
In 2005 the UN Human Rights Commission (later replaced by the UN Human Right Council) solicited the UN Secretary -General to appoint a special representative on the issues of human rights and transnational corporation and other business enterprises (Resolution Number E/CN.4/RES/2005/69). At the time Kofi Anan the Secretary- General appointed Professor John Ruggie of the Harvard University to work as the Special Representative. Four main functions were mandated to the Special Representative and the Professor conducted comprehensively research and discussions with experts and representatives of governments, business and civil society in diverse regions of the globe. On 18 June 2008 Professor Ruggie proposed to the Human Right Council a policy framework for managing business and human rights which contained three main principles: the state duty to protect against human rights abuses by third parties, including business, through appropriate policies, regulations and adjudication; the corporate responsibility to protect human rights, which means to act with due diligence to avoid infringing on the rights of others; and the need for greater access by victims to effective remedies, judicial and non judicial. The Council highly appreciated the effort of Special Representative and mandated another 3 years' time to provide recommendations on ways in which to operationalize and strengthen the framework. Later in the 2011 Professor Ruggie submitted the "Guiding Principles on Business and Human Rights for implementing by the United Nations 'Protect, Respect and Remedy' framework" in his final report to the Human Rights Council and on16 June 2011 it was unanimously endorsed by the Council with consensus (Resolution number A/HRC/RES/17/4). With this extraordinary hard work of the Special Representative, his mandate concluded in June 2011.

Guiding Principles on Business and Human Rights for implementing the United Nation 'Protect, Respect and Remedy' framework (Guiding Principle) is considered as the prime and detailed recognized document relating to human rights and business. The Guiding Principle recommends the implementation in a non-discriminatory manner and to be understood coherently in terms of the objective of enhancing standards and practices with regard to business and human rights and contribute to sustainable globalization. This Guiding Principle consists of three major general principles as follows:

1. State's existing obligation to respect' protect and fulfill human rights and fundamental freedoms; 
2. The role of business enterprises as specialized organs of society performing specialized functions are, required to comply with all applicable laws and to respect human rights;

3. The need for rights and obligations to be matched to appropriate and be effective when breached.

Detailed discussion of the principles recognized in this Guiding Principle will be discussed in the later part of this research paper.

In the same year 2011, the UN Human Right Council established a working Group on business and human rights which consists of five members of balanced geographical representation, for a period of three years. The Working Group is expected to act as the guarantor of the integrity of the Guiding Principles (Michael, 2014). According to the mandate of the working group many functions relating to Guiding Principles are required, such as to promote the effective implementation, to identify, exchange and promote good practices and lessons, promote capacity-building, to work in close cooperation and coordination with other relevant special procedures of the Human Rights Council, to develop a regular dialogue and discuss possible areas of cooperation with Governments and all relevant actors and to report annually to the Human Rights Council and the General Assembly. In June 2014 at its twentysixth session (in resolution 26/22), the Human Rights Council decided to extend the Working Group's mandate for a period of three years.

In the year 2014, the UN Human Rights Council adopted two resolutions; one resolution was to establish an 'Intergovernmental Working Group' with the mandate to elaborate an international legally binding instrument on Transnational Corporations and Other Business Enterprises with respect to human rights. The other resolution was aimed at preparing a report considering, among other things, the benefits and limitations of a legally binding instruments by the UN Working Group on business and human rights. Under the mandate of the first resolution in 2014, a discussion was started to implement a binding treaty on this matter. However, Professor Roggie J.G, Special Representative from 2005- 2011 was of the view that after the first session of the Intergovernmental Working Group, it was challenging to get the consensus of governments for a legally binding treaty and civil society has to play a major role in this regard till the new treaty implemented. 
In relation to the complaint mechanisms of violation of human rights the OECD Guideline for Multinational Enterprises - 2011 (Organization for Economic Cooperation and Development) provides a set of voluntary principles, including on human rights, with a complaints procedure. The Guidelines apply to multinational firms operating in or from the 34 OECD participating countries and 10 non-member countries. Additionally some sectoral initiatives have been taken as voluntary initiatives to address human rights issues and these sectors involve Non Governmental Organizations (NGO), governments and/or international organizations, to enter into. Some key initiatives include: Conflict-Free Sourcing Initiative, Electronic Industry Citizenship Coalition, Equator Principles, Fair Labour Association, Extractive Industries Transparency Initiative and Global Network Initiative. Further it was noted that some of the sectoral initiatives such as Accord on Fire and Building Safety in Bangaladesh and Fair Food Standards Council in USA involved companies led by workers and communities who were directly impacted. Among these efforts different groups have taken some initiatives to operationalise human right in business. The Global Business Initiative on Human Rights, Business for Social Responsibility, Danish Institute for Human Rights, Institute for
Human Rights and Business can be taken as examples of groups relating to this matter.

Apart from the above UN materials, the International Labour Organisation (ILO) also has created some conventions as the main authoritative body of working on labour rights. As a core document the Declaration on Fundamental Principles and Rights at Work can be identified and it commits all its member States to four categories of principles and rights: freedom of association and the right to collective bargaining; the elimination of compulsory labour; the abolition of child labour; and the elimination of discrimination in respect of employment and occupation. These rights are also covered by the eight core conventions of the International Labour Organization (ILO).

\section{Examples of business impact on human rights}

The commitment to respect human rights would grant benefits for business corporations. Loyalty to human rights would serve to provide protection in domestic and international legal rules which ensure that business actions are consistent and according to the required rules and this will avoid facing legal challenges in their local and local activities. These human rights also 
would help to build satisfied customers and employees and this will direct to increase the productivity of the business. The good name created by adhering to human rights standards can be marketed in the media and this would help Business Corporation to establish their company and brand names on the consumers mind. Consumers will remind the company as an organ which would enhance and protect the rights of individuals and not as a place which exploit the individuals rights. This will also help to create good will with the company and this will give benefits to the business in return. Therefore it has emerged that, one of the central measures of a company's social responsibility is its respect human rights. And while most companies recognize the moral imperative to operate consistently with human rights principles, recognition is growing that respect for human rights can also be a tool for improving business performance (Robinson, 2000).

Human rights are included in many international documents and UDHR is the initial and most effective document. Although it is a part of soft law which does not transfer a legal binding duty in the initial level, today this document is considered as the part of customary international law which provides a legal binding value. The UDHR awarded the Guinness World Record for being the most translated - indeed, the most "universal" - document in the world. The basic 30 articles contained in the UDHR have elaborated in deferent volume in diverse other conventions which came in to affect after the UDHR. For example, the nondiscrimination based on the sex and genders have been addressed more comprehensively in the Convention on the Elimination of all Forms of Discrimination against Women (CEDAW). The freedom from torture and ill-treatment which was a one single right of the UDHR, has been discussed in detail in the United Nations Convention against Torture and Other Cruel, Inhuman or Degrading Treatment or Punishment (UNCAT) which was enacted in 1984.

A business can impact on the right of individuals in many ways and following are some examples of situations where this conflict can take place. 
Table 01: Business Impact on Human Rights

\begin{tabular}{|c|c|c|}
\hline Recognized right & $\begin{array}{l}\text { Recognized } \\
\text { Convention or } \\
\text { document }\end{array}$ & Affected example Situation/s \\
\hline $\begin{array}{l}\text { Right to enjoy just } \\
\text { and favourable } \\
\text { conditions of work }\end{array}$ & $\begin{array}{l}\text { Article 23;UDHR, } \\
\text { Article 5;ICESCR, } \\
\text { Article 5; CEDAW, } \\
\text { Article } 11 \text {; CRC }\end{array}$ & $\begin{array}{l}\text { Exposure of workers to hazardous working } \\
\text { conditions without adequate safety equipment }\end{array}$ \\
\hline Right to life & $\begin{array}{l}\text { Article 03; UDHR, } \\
\text { Article 06; ICCPR }\end{array}$ & $\begin{array}{l}\text { A company produces a product with exposure to } \\
\text { toxic chemicals. }\end{array}$ \\
\hline $\begin{array}{l}\text { Right of self- } \\
\text { determination }\end{array}$ & $\begin{array}{l}\text { Article } 01 \text {; ICCPR } \\
\text { and ICESCR }\end{array}$ & $\begin{array}{l}\text { Acquisition of indigenous peoples' lands to } \\
\text { construct a business. }\end{array}$ \\
\hline $\begin{array}{l}\text { Freedom from } \\
\text { torture and ill- } \\
\text { treatment }\end{array}$ & $\begin{array}{l}\text { Article } 5 \text {;UDHR, } \\
\text { Article } 7 \& 10 \text { of } \\
\text { ICCPR, UNCAT }\end{array}$ & $\begin{array}{l}\text { Failure to foster a workplace that is free from } \\
\text { severe forms of harassment that cause serious } \\
\text { mental distress }\end{array}$ \\
\hline $\begin{array}{l}\text { Freedom from } \\
\text { slavery }\end{array}$ & $\begin{array}{l}\text { Article } 4 \text {; UDHR, } \\
\text { Article } 8 \text {; ICCPR }\end{array}$ & $\begin{array}{l}\text { Businesses use trafficked labour of workers who } \\
\text { have been forced to work as slaves. }\end{array}$ \\
\hline $\begin{array}{l}\text { Rights to liberty and } \\
\text { security of the } \\
\text { person }\end{array}$ & $\begin{array}{l}\text { Article } 3 \text {; UDHR, } \\
\text { Article } 9 \text {; ICCPR }\end{array}$ & $\begin{array}{l}\text { A company whose supplier routinely allows sexual } \\
\text { abuse of female workers to go unaddressed in their } \\
\text { workplace. }\end{array}$ \\
\hline $\begin{array}{l}\text { Right to freedom of } \\
\text { movement }\end{array}$ & $\begin{array}{l}\text { Article } 13 \text {; UDHR, } \\
\text { Article } 12 \text {; ICCPR }\end{array}$ & $\begin{array}{l}\text { Employers withholding workers' identification } \\
\text { documents. }\end{array}$ \\
\hline Right to a fair trial & $\begin{array}{l}\text { Article } 10 \text {; UDHR, } \\
\text { Article } 14 \text {; ICCPR }\end{array}$ & $\begin{array}{l}\text { A business tries to corrupt the judicial process by } \\
\text { destroying relevant evidence or by seeking to } \\
\text { bribe or otherwise influence judges or witnesses to } \\
\text { take certain actions or make certain statements. }\end{array}$ \\
\hline Right to privacy & $\begin{array}{l}\text { Article } 12 \text {; UDHR, } \\
\text { Article } 17 \text {; ICCPR }\end{array}$ & $\begin{array}{l}\text { Requiring pregnancy testing as part of job } \\
\text { applications }\end{array}$ \\
\hline $\begin{array}{l}\text { Rights of protection } \\
\text { for the child }\end{array}$ & $\begin{array}{l}\text { Article } 25 \text {; UDHR, } \\
\text { CRC }\end{array}$ & $\begin{array}{l}\text { Business activities that involve hazardous work } \\
\text { (such as cutting sugar cane or mining) performed } \\
\text { by persons under the age of } 18 .\end{array}$ \\
\hline $\begin{array}{l}\text { Right to equality } \\
\text { before the law, equal }\end{array}$ & $\begin{array}{l}\text { Article } 1,7, \& 10 ; \\
\text { UDHR, } \\
\text { Article } 3,14,23 \& \\
\text { 26; ICCPR }\end{array}$ & $\begin{array}{l}\text { Indirectly discriminating in the recruitment, } \\
\text { remuneration or promotion of workers, for } \\
\text { example, by offering a training programme that } \\
\text { enhances an individual's chance of promotion at a } \\
\text { time that is reserved for religious observance by a } \\
\text { particular group. }\end{array}$ \\
\hline
\end{tabular}




\begin{tabular}{|l|l|l|}
\hline $\begin{array}{l}\text { Right to form and } \\
\text { join trade unions }\end{array}$ & $\begin{array}{l}\text { Article 23; UDHR, } \\
\text { Article 22; ICCPR, } \\
\text { Article 8; ICESCR }\end{array}$ & $\begin{array}{l}\text { Creating barriers to the formation of trade unions } \\
\text { among employees or contract workers }\end{array}$ \\
\hline $\begin{array}{l}\text { Right to social } \\
\text { security }\end{array}$ & $\begin{array}{l}\text { Article 22; UDHR, } \\
\text { Article 10; ICESCR }\end{array}$ & $\begin{array}{l}\text { Denying workers their contractually agreed } \\
\text { employment injury benefits. }\end{array}$ \\
\hline $\begin{array}{l}\text { Right to an adequate } \\
\text { standard of living }\end{array}$ & $\begin{array}{l}\text { Article 25; UDHR, } \\
\text { Article 11; ICESCR }\end{array}$ & $\begin{array}{l}\text { Failing to provide adequate sanitation facilities for } \\
\text { workers in a company-owned factory. }\end{array}$ \\
\hline $\begin{array}{l}\text { freedom of thought, } \\
\text { conscience and } \\
\text { religion }\end{array}$ & $\begin{array}{l}\text { Article 18; UDHR, } \\
\text { Article 18; ICCPR }\end{array}$ & $\begin{array}{l}\text { A company does not allow its workers to seek } \\
\text { reasonable time off for their religious holidays. }\end{array}$ \\
\hline $\begin{array}{l}\text { Rights to freedom of } \\
\text { opinion and } \\
\text { expression }\end{array}$ & $\begin{array}{l}\text { Article 19; UDHR, } \\
\text { Article 19; ICCPR }\end{array}$ & $\begin{array}{l}\text { Operating in a country where workers are } \\
\text { routinely prevented by law from expressing their } \\
\text { opinions in the public domain. }\end{array}$ \\
\hline $\begin{array}{l}\text { Rights of protection } \\
\text { of the family and the } \\
\text { right to marry }\end{array}$ & $\begin{array}{l}\text { Article 16; UDHR, } \\
\text { Article 23; ICCPR }\end{array}$ & $\begin{array}{l}\text { Article 12; ICESCR } \\
\text { the basis of their marital or reproductive status. }\end{array}$ \\
\hline $\begin{array}{l}\text { Right to health } \\
\text { Right to education. }\end{array}$ & $\begin{array}{l}\text { Article 26; UDHR, } \\
\text { negative impacts on the health of workers and/or } \\
\text { surrounding communities. }\end{array}$ \\
\hline
\end{tabular}

\section{The principles which should be}

followed by a business

\section{corporation.}

The basic principles which have to be adhered by business enterprises have been mentioned clearly in the Guiding Principles on Business and Human Rights for implementing the United Nation 'Protect, Respect and Remedy' framework.
In relation to respect human rights, business enterprises should avoid infringing on the human rights of others and should address the adverse impacts of human rights(Principle1). This responsibility to respect human rights applies to all enterprises regardless of their size, sector, operational context, ownership and structure (Principle 4). The scope of human rights refers to internationally 
recognized human rights - understood, at a minimum, as those expressed in the International Bill of Human Rights and the principles concerning fundamental rights set out in the International Labour Organization's Declaration on Fundamental Principles and Rights at Work (Principle 2). Principle 3 spell out that the nature of conducting a business enterprises should show respect to human rights such as; avoiding causing or contributing to adverse human rights impacts through their own activities, addressing such impacts when they occur, seeking to prevent or mitigate adverse human rights impacts that are directly linked to $r$ operations, products or services by their business relation ships, even if they have not contributed to causing those impacts.

In respect of the actions that have to be taken by a business enterprises, it is required to put forwarded policies and processes appropriate to their size and circumstances, including: (a) A policy commitment to meet their responsibility to respect human rights; (b) A human rights due diligence process to identify, prevent, mitigate and account for how they address their impacts on human rights; (c) Processes to enable the remediation of any adverse human rights impacts caused or to which they contribute (Principle 5). This commit-ment of statement is desirable to be approved at the most senior level and consists of expectations of all stake holders. Further this has to be publicly available and communicated internally and externally to all personnel, business partners and other relevant parties (Principle 6).

Dealing with the issue of preventing, mitigating and accounting for adverse human rights impacts business enterprises should carry out human rights due diligence as following prescribe manners. (a) Business enterprises should cover adverse human rights impacts that the business enterprise may cause or contribute to through its own activities, or which may be directly linked to its operations, products or services by its business relationships; (b) this due diligence will vary in complexity with the size of the business enterprise, the risk of severe human rights impacts, and the nature and context of its operations; (c) Due diligence Should be ongoing, recognizing that the human rights risks may change over time as the business enterprise's operations and operating context evolve (Principle 7).

Gauging human rights risks is also important and this process has to be conducted by internal and/or independent external human rights expertise which involves meaningful consultation with potentially affected groups and 
other relevant stakeholders, as appropriate to the size of the business enterprise and the nature and context of the operation (Principle 8). To prevent and mitigate adverse human rights impacts it is required for business enterprises to integrate the findings from their impact assessments across relevant internal functions and processes and take appropriate action (Principle 9). Further busin-ess enterprises should track the effectiveness of their response to verify whether adverse human rights impacts are being addressed and this tracking should be based on appropriate qualitative and quantitative indicators and drawn on feedback from both internal and external sources, including affected stakeholders (Principle 10).

Principle 11 has referred to the ways in which business enterprises should externally communicate their human rights impacts, particularly when concerns are raised by or on behalf of affected stakeholders. Especially the business enterprises whose operations or operating contexts pose risks of severe human rights impacts should report formally on how they address them. In such a situation where business enterprises identify that they have caused or contributed to adverse impacts, it is necessary for them to provide for or cooperate in their remediation through legitimate processes
(Principle 12). Principle 13 speaks about the necessity of compliance with laws and respect internationally recognized human rights, wherever businesses operate. In the conflict of prioritizing actions to address actual and potential adverse human rights impacts, business enterprises should first seek to prevent and mitigate those that are most severe or where delayed response would make them irremediable (Principle 14).

Apart from the above detailed principle, The UN Global Compact also provides 10 main principles that are derived from major international human rights, The Rio Declaration on Environment and Development and the United Nation Convention Against Corruption. These principles are as follows.

Principle 1: Businesses should support and respect the protection of internationally proclaimed human rights;

Principle 2: make sure that they are not complicit in human rights abuses.

Principle 3: Businesses should uphold the freedom of association and the effective recognition of the right to collective bargaining;

Principle 4: Elimination of all forms of forced and compulsory labour;

Principle 5: Effective abolition of child labour; 
Principle 6: Elimination of discrimination in respect of employment and occupation.

Principle 7: Businesses should support a precautionary approach to environmental challenges;

Principle 8: Undertake initiatives to promote greater environmental responsibility;

Principle 9: Encourage the development and diffusion of environmentally friendly technologies.

Principle 10: Businesses should work against corruption in all its forms, including extortion and bribery.

\subsection{Analysis.}

According to the above discussion it is clear that there are certain amounts of human rights protection which have to be insured by any business enterprises. Principles of the Guiding Principles spell out the steps that have to be followed by a business enterprise. However some of the business organizations counter this human rights responsibility saying that human rights are not for them and it is only to describe the relationship between government and individuals. This is not an acceptable argument as every business enterprise is also covered by the meaning of UDHR as describes below. In the preamble of the UDHR it is stated that every individual and every organ of society' has a responsibility to protect and respect human rights. International law scholar Lousi Henkin(1999) noted that 'every individual and every organ of society excluded no one, no company, no market, no cyberspace. The UDHR applies to them all'. Apart from this point it also highlights the state party responsibility of protecting individuals from harm caused by a third party. State parties are under an obligation to take every step in such situations. Therefore it is well established that in the current context all the business enterprises should give adequate attention to the human rights standards which they have to follow.

One good point about the above the principles are that they apply irrespective of the size of the Business Corporation and locality. However severity of impacts will be evaluated by their scale, scope and irremediable nature. It is obvious that a large company faces a more complex situation than a small company. Their numbers of employees are high; the area they work in might be bigger, their supply chains might be complex, they might work at international level; therefore the impact might be high. The Guiding Principle prescribes each and every enterprise to conduct regular human right analysis with the support of the external human 
rights expertise. This outside intervention is important to establish the independency of the human right report. If the government has some compulsory laws to provide a human rights auditing report at the end of each year, this would help to provide a human face to this global world. This has been adopted by some countries and in any event, human rights reporting requirements are already mandatory in some EU countries, including the United Kingdom, Denmark, France, Norway and Sweden, and also countries that exist outside the EU, for example, in Switzerland. Companies are expected to report on the human rights impacts with respect to their entire value chain (Write \& Clarke, 2015). In particular, Europe companies which have more than 500 employees are required to issue a nonfinancial human rights reporting in European Union (EU) countries and failure to align with this becomes a criminal offence which has resulted in providing individually liability for both company and directors. In addition, some governments are taking action to address particular issues such as forced labour and human trafficking. For example, in the United States there is law in the California Transparency in Supply Chain Act of 2010, which obliges large businesses to reveal the strategies they have put in place to report on human trafficking in their supply chains. According to this new legislation business cooperation will need to report on slavery and human trafficking issues. In today's context, it can be noted that most of the companies are engaging in Corporate Social Responsibility (CSR) projects. However most of them are selective in nature as to what they voluntarily like to address. Therefore there can be situations where major issues are forgotten while addressing only minor issues. However if a company can have a good non-financial human rights assessment yearly they can easily pick an issue which causes major damage and they can later invest in that issue under SCR scheme. That should be a more meaningful way of engaging in CSR projects. With regard to these human rights reporting it should be noted that in 2015, Unilever Company became worldwide recognized as the initial company to publish a human rights report based on the UN Guiding Principles Reporting Framework. The report highlights Unilever's efforts to embed and promote human rights practices in the business. It identified the salient issues faced by the company as discrimination, fair wages, forced labour, freedom of association, harassment, health and safety, land rights and working hours. With potentially millions of stakeholders in the organisation's value chain, Unilever operates an eco-system in which it can control 
some parts and only influence others. Unilever identified issues of harassment as the issue that was most often reported internally in 2014, particularly in the agricultural sector. In response, the company launched three initiatives to combat sexual harassment in the Kericho tea plantation in Kenya. Community outreach, safety talks and targeted training exercises have led to positive results and ongoing progress will be publicly reported (Barman, 2016).

One of the other major issues regarding this matter is enabling a legally binding convention which binds state parties and all stakeholders. In the Guiding Principle, it is their voluntary consent to adhere to these rules and understand the benefit which they can get by adhering to this framework. As a result a substantial amount of people who work on this area such as international institutions, Non-governmental agencies, and courts have sought ways to hold these business enterprises responsible for the violations of human rights. There have been calls for a binding treaty regulating human rightsrelevant conducts of business enterprises within inter-national law (UNHRC, 2014; Weschka, 2006; Hazenberg, 2015). In the year 2014 there was an attempt by the Intergovern-mental Working Group to have an international legally binding instrument on Transnational Corporations and Other Business Enterprises with respect to human rights. However, it is in the very early stage and even the first session was not successful. Governme-nts which have many connections with the business corporations are showing a lethargic attitude in having such legally binding document. However here the researcher intends to call upon non-governmental agencies and civil societies to come together and pressure governments to force this binding law.

\subsection{Conclusion}

1. Meaning of human rights covers the all rights which are mentioned in main international documents such as UDHR, ICCPR, ICESCR, CRC, CEDAW, etc. Although the UDHR is a declaration, by today it is a legally binding document. Therefore, all individuals and social organs such as business enterprises are bind with the obligation provided by international conventions. Business enterprises are clearly in the coverage of UDHR and other Conventions and obliged to adhere to human rights standards.

2. Irrespective of the size and the locality of the business all the business enterprises are guided by the Guiding Principles to follow human rights standard. However this is a non-legal 
binding document and therefore this has created reluctances among business enterprises to adhere to the Guiding Principles.

3. Other than the Guiding Principles, all the Business enterprises have a legal obligation to protect and respect the fundamental rights law recognized within the territory of the country. Non-compliance with the recognized rights can be questioned in the courts.

4. The companies which adhere to human rights standards and are conducting the regular human rights reporting are appreciated by the society and these positive engagements with human rights standards have given them many benefits which include high profits, satisfied customers and employees. Therefore, it is recommended to include human rights reporting as a compulsory requirement for all business enterprises. As an initial level it is desirable to include a statement of human right commitment by every business enterprise. This procedure would lead to a greater transparency and accountability in future corporate actions.

5. For the acceleration of the human rights adherence by all the business enterprises in the world it is advisable to enable a legal binding convention which provides a legal binding authority. This will lead State party to establish enabling legislations in domestic legal structure which finally provide legal obligation towards business enterprises. This also will grant an opportunity for human rights victims to file case against business enterprises that have violated the set human rights law in the country. 


\section{References}

Alberts, T. (2013). A human rights based approach to business? Retrieved from Busi-ness and Human Rights Resource Centre website: https://business-humanrights. org/en/ahuman-rights-based-approach-to-business[accessed on 16-05-2017]

Barman, T. (2016). Business and Human Rights Evolution and Acceptance; CGMA guidance for assessing and protecting human rights. Retrieved from Chartered Global management Accountant's website. htps:/www.cgma.org/ resources/ reports/ business-and-human-rights.html[accessed on 20-04-2017]

Arthurs, H.W. (1983). Law and Learning: Report to the Social Sciences and Humanities Research Council of Canada by the Consultative Group on Research and Education in Law, Information Division, Social Sciences and Humanities Research Council of Canada, Ottawa.

Chynoweth, P. (2008). Advanced Research Methods in the Built Environment, Knight, A. \& Ruddock, L. (Eds.), Three Legal research, (chap 3),Blackwell.

Hart, H.L.A. (1961). The Concept of Law, Clarendon Press, Oxford.

Kelsen, H. (1967). The Pure Theory of Law ( Knight, M. Trans.) University of California Press, Berkeley, California

Hazenberg J. L. J. (2015). Transnational Corporations and Human Rights Duties:

Perfect and Imperfect, Human Rights Review pp.479-500. Available in https://ink. springer.com/ content/pdf/10.1007\%2Fs12142-016-0417-3.pdf[accessed on 10-052017]

Henkin, L. (1999). Human Rights, New York : Foundation Press.

International Labour Organization (ILO), ILO Declaration on Fundamental Principles and Rights at Work, June 1988, available at: http://www.refworld. org/docid/ 425bbdf 72. html [accessed 21 June 2017

Michael, K. (2014). The Reality of the United Nations Guiding Principles on Business and Human Rights. Human Rights Law Review 2014; 14 (1): 133-147. doi: 10.1093/hrlr/ngt041

Organisation for Economic Cooperation and Development (OECD), OECD (2000) Guidelines for Multinational Enterprises, 27 June 2000, available at: http://www. refworld.org/docid/425bd34c4.html [accessed 21 June 2017]

Robinson, M. (2000). Bussiness and Human Rights: A Prograss Report. UN High Commission for Human Rights, Geneva. available in http://www.ohchr.org /Documents/Publications/BusinessHRen.pdf[accessed on 01-04-2017]

Ruggie, J. (2008). Protect, Respect and Remedy: a Framework for Business and Human Rights. Report of the Special Representative of the Secretary-General on the issue of human rights and transnational corporations and other business enterprises. 
A/HRC/8/5. Retrieved from https://documents-dds ny.un.org/doc /UNDOC/ GEN/G08/128/61/PDF/G0812861.pdfAOpenElement[accessed on 01-04-2017]

The Danish Institute for Human Rights (DIHR), A human rights based approach (HRBA) incorporates international human rights standards into development work. https://www.humanrights.dk/our-work/human-rights-based-approach (Acceded during 01-02-2017-31-06-2017

UNICEF- Human Rights-based Approach to Programming. Unicef web site. https://www.unicef.org/policyanalysis/rights/index_62012.html (Acceded during 01-02-2017-31-06-2017.

United Nations, Charter of the United Nations (1945). 24 October 1945, 1 UNTS XVI, available at: http://www.refworld.org/docid/3ae6b3930.html [accessed 21 June 2017]

UN General Assembly, International Covenant on Civil and Political Rights, 16 December 1966, United Nations, Treaty Series, vol. 999, p. 171, available at: http://www.refworld.org/docid/3ae6b3aa0.html [accessed 21 June 2017]

UN General Assembly, International Covenant on Economic, Social and Cultural Rights(1966) 16 December 1966, United Nations, Treaty Series, vol. 993, p. 3, available at: http://www.refworld.org/docid/3ae6b36c0.html [accessed 21 June 2017]

United Nationas, Office of the High Commissioner,(2011). Guiding Principles on Business and Human Rights for implementing the United Nation 'Protect, Respect and Remedy' framework. New york and Geneva. available at: http://www. ohchr.org/ Documents/Publications/Guiding Principles Business HR_EN.pdf

UN General Assembly, Universal Declaration of Human Rights (1948). 10 December 1948, 217 A (III), available at: http://www.refworld.org/docid/3ae6b3712c.html [accessed 21 June 2017]

Weschka, M. (2006). Human Rights and Multinational Enterprises: How Can Multinational Enterprises Be Held Responsible for Human Rights Violations Committed Abroad $\Delta$ Heidelberg Journal of International Law 66: 625-661

Whelan, G., Moon, J., Orlitzky, M. (2009) Human Rights, Transnational Corporations and Imbedded Liberalism: What Chance Consensus $\Delta$ Journal of Business Ethics, 87: 374

Wright J.E \& Clarke J.J. (2015). How Can Businesses Impact Human Rights. available in $\Delta \mathrm{http} / / /$ www.ungpreporting.org/resources/how-businesses-impacthuman-rights/[accessed on 03-003-2017] 